\title{
Ultrastructure of a spiral micro-organism from pig gastric mucosa ("Gastrospirillum suis")
}

\author{
E. N. MENDES, DULCIENE M. M. QUEIROZ, G. A. ROCHA, SILVIA B. MOURA, \\ VIRGINIA H. R. LEITE* and M. EVANGELINA F. FONSECA ${ }^{\dagger}$
}

Laboratory of Research in Bacteriology and *Electron Microscopic Centre 'Faculdade de Medicina' UFMG, Av. Alfredo Balena, 190-CEP 30130, Belo Horizonte, MG, and TElectron Microscopic Unit 'Instituto de Microbiologia' UFRJ, Rio de Janeiro, RJ, Brasil

\begin{abstract}
Summary. The ultrastructural features of a helical-shaped bacterium occurring in the stomach of pigs, within the mucus on the mucosal surface of antral pits, were examined. The bacterial cell had three to eight spiral turns, flattened and truncated ends and was approximately $4.0 \mu \mathrm{m}$ long and $0.6 \mu \mathrm{m}$ wide. In some sections, up to six flagella, about $22 \mathrm{~nm}$ in diameter, were seen arising from each pole. The cytoplasm contained sparse, irregular granules, numerous ribosomes and large single-layered membrane-bound granules. In the flagella insertion area, there was a highly electrondense component, the "polar membrane". This micro-organism differed from similar bacteria described in cats, dogs and monkeys, and may cause inflammation in the antral mucosa of pigs similar to Helicobacter pylori infection in man. Furthermore, it was morphologically similar to the spiral micro-organism distinct from $H$. pylori which has been described recently in human antral mucosa from patients with gastritis and may be of potential significance as a pathogen in man. The name "Gastrospirillum suis" is proposed for this bacterium.
\end{abstract}

\section{Introduction}

Spiral micro-organisms have been seen in the gastric mucosa of various mammals. ${ }^{1-5}$ In several species, such as cats, dogs and monkeys, they do not seem to produce pathological changes and are probably normal inhabitants of the fundic glands. ${ }^{2,5,6}$ However, there is now strong evidence that a spiral micro-organism, Helicobacter pylori, is the most common and important cause of gastritis in man. $^{7}$

In this paper we report details of the ultrastructure of a spiral-shaped bacterium occurring in the gastric mucosa of pigs. This micro-organism differed from the gastric spiral bacteria of other host species and may cause inflammation in the antral mucosa of pigs. ${ }^{8}$ Better comprehension of this type of host-parasite relationship could add to our understanding of the pathogenesis of human antral gastritis caused by $H$.pylori. Furthermore, as tightly spiralled micro-organisms morphologically similar to the pig bacterium have been observed on human antral mucosa affected by gastritis, $, 5,8,10,11$ the potential role of this organism as a human pathogen requires consideration.

Received 5 Jan. 1990; accepted 19 March 1990.
The aim of the present investigation was to study the antral mucosa of pig stomach by electronmicroscopy to determine the morphological characteristics of the spiral micro-organisms and their relationship to the gastric epithelial cells. Additionally, the morphological features of the spiral bacteria were compared with those of other gastric spiral organisms.

\section{Materials and methods}

\section{Specimens}

Stomachs of slaughtered pigs, opened longitudinally along the greater curvature, were thoroughly washed with tap water and four samples were collected from the antral region of each. One sample was placed in a tube containing Christensen's urea broth ${ }^{12}$ and left at room temperature for up to $1 \mathrm{~h}$. The second sample was smeared on a glass slide, stained by carbol fuchsin $40 \%$ and examined by light microscopy. The remaining two samples were placed in $1 \mathrm{ml}$ of PBS (pH 7.2) in an ice bath. When the urease test was positive and tightly spiralled rods were seen in the smears, the samples placed in PBS were processed for electronmicroscopy and scrapings from the antral mucosa were collected for negative staining. 


\section{Preparations for electronmicroscopy}

Fixing, embedding and sectioning. Specimens were fixed in glutaraldehyde $2.5 \% \mathrm{v} / \mathrm{v}$ buffered with $0.1 \mathrm{M}$ sodium cacodylate, $\mathrm{pH} 7 \cdot 2$, for $2 \mathrm{~h}$ at room temperature and then placed in three changes of $0.1 \mathrm{~m}$ sodium cacodylate for 10 min each. The fragments were post-fixed in osmium tetroxide $1 \% \mathrm{w} / \mathrm{v}$ buffered with $0 \cdot 1 \mathrm{M}$ sodium cacodylate, $\mathrm{pH} 7 \cdot 2$, for $40 \mathrm{~min}$ at room temperature. After postfixation the material was washed three times with $0.1 \mathrm{M}$ sodium cacodylate containing $0 \cdot 1 \mathrm{M}$ saccharose for 10 min each and treated for 10 min with uranyl acetate $5 \% \mathrm{w} / \mathrm{v}$. The fixed samples were dehydrated in a graded alcohol series (ethanol $30,50,70$ and $90 \%$ for $10 \mathrm{~min}$ each and $100 \%$ for $1 \mathrm{~h}$ ) and in acetone for $5 \mathrm{~min}$. The specimens were embedded in Polylite 8001 (Resana S/A-Brasil) according to the method of Coiro et al. ${ }^{13}$. The material was cut on a 2088 LKB ultramicrotome with diamond knives and the sections $(60-90 \mathrm{~nm})$ were collected on 400 mesh copper grids. The sections were stained with uranyl acetate $5 \% \mathrm{w} / \mathrm{v}$ for $10 \mathrm{~min}$ and lead citrate for $5 \mathrm{~min}$.

Negative staining. A sterilised solution containing mannose $1 \%$, saccharose $1 \%$ and casaminoacids $0 \cdot 1 \%$ $\mathrm{w} / \mathrm{v}$ was added to scrapings from antral mucosa of a stomach selected as described above. The mixture was incubated for $30 \mathrm{~min}$ at $37^{\circ} \mathrm{C}$ with gentle agitation and centrifuged for $2 \mathrm{~min}$ at $190 \mathrm{~g}$. The supernate was transferred to a microcentrifuge tube and centrifuged at $11000 \mathrm{~g}$ for $5 \mathrm{~min}$. One drop of the resultant pellet was applied to formvar-coated 300-mesh copper grids for 1 min. Excess fluid was removed and replaced with a drop of phosphotungstic acid $1 \% \mathrm{w} / \mathrm{v}$, adjusted to $\mathrm{pH} 7.2$ with $\mathrm{NaOH}$, which was immediately removed.

Scanning electronmicroscopy. Fragments of antral gastric mucosa were smeared on coverslips, fixed in glutaraldehyde $2.5 \% \mathrm{v} / \mathrm{v}$ buffered with $0.1 \mathrm{M}$ sodium cacodylate, $\mathrm{pH} 7 \cdot 2$, for $2 \mathrm{~h}$ and post-fixed in osmium tetroxide $1 \% \mathrm{w} / \mathrm{v}$ in $0.1 \mathrm{M}$ sodium cacodylate buffer, $\mathrm{pH}$ $7 \cdot 2$ for $40 \mathrm{~min}$. They were washed three times with $0.1 \mathrm{M}$ sodium cacodylate containing $0.1 \mathrm{M}$ saccharose for 10 min each, dehydrated in an alcohol series (ethanol 30, 50, 70,8090 and $100 \%$ for $10 \mathrm{~min}$ each) and critical-point dried. They were then mounted on to stubs and coated with gold in a Balzers FL 9496 apparatus.

\section{Electronmicroscopy}

Specimens were examined for transmission electronmicroscopy with a Philips EM-301 and for scanning electronmicroscopy with a JEOL-255 I electronmicroscope.

\section{Results}

Transmission electronmicroscopy of preparations of pig stomach showed large groups of distinctive spiral micro-organisms within the mucus on the mucosal surface of antral pits (fig. 1). The bacteria did not penetrate deeply into the glands and were not found inside the host cells. In some sections the bacteria were seen in intercellular spaces. The cell walls of some bacteria were in intimate contact with cell membrane (fig. 2).

The bacteria were helical shaped and had 3-8 (mean 5) complete spiral turns per cell; they were 1.5-5.2 (mean 4.0) $\mu \mathrm{m}$ long and 0.4-0.7 (mean $0.6) \mu \mathrm{m}$ wide and had truncated and flattened ends (figs. 1 and 2). At higher magnification, the cytoplasm was seen to be enclosed by an inner

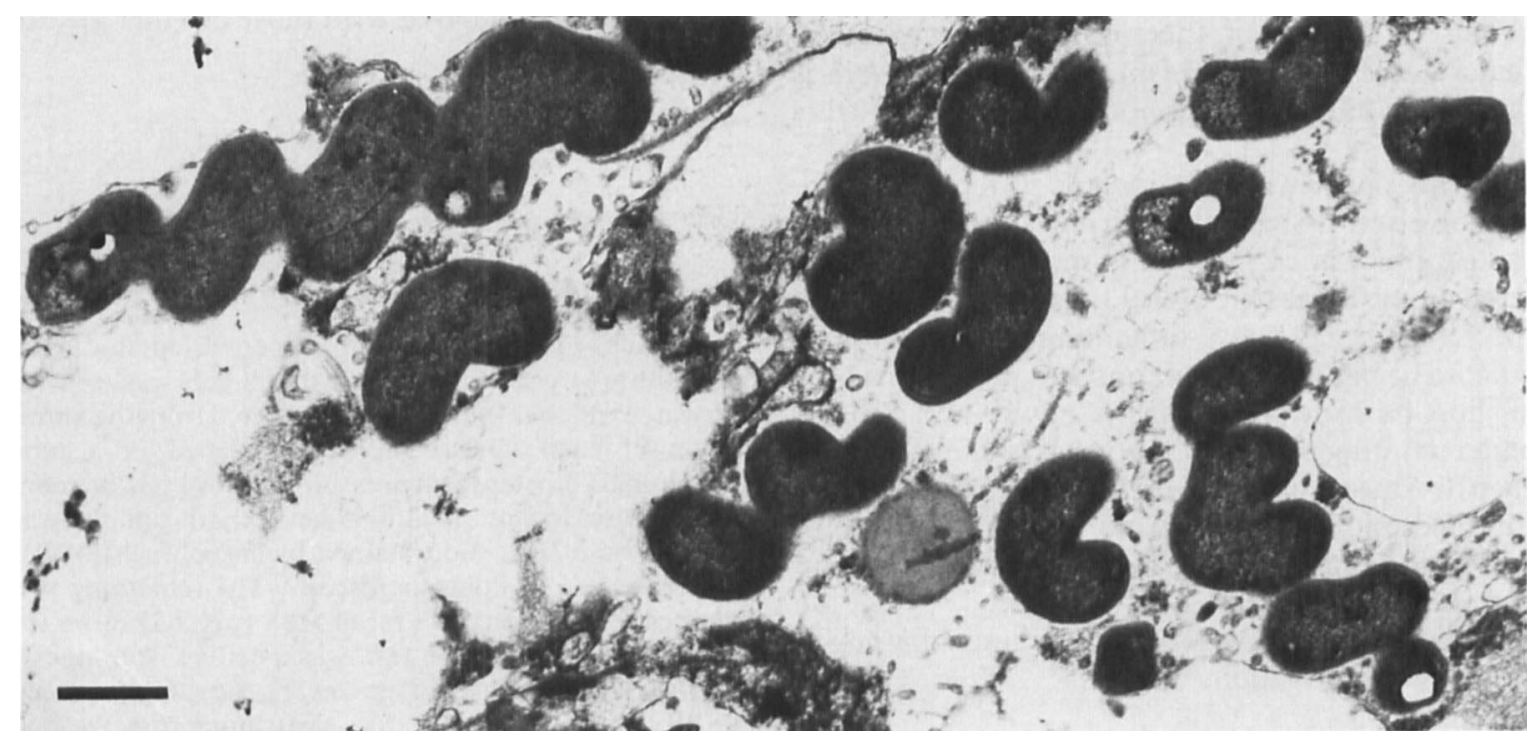

Fig. 1. Transmission electronmicrograph showing numerous sections of spiral-shaped bacteria in mucus of the antral region of a pig stomach. Bar, $0 \cdot 5 \mu \mathrm{m}$. 


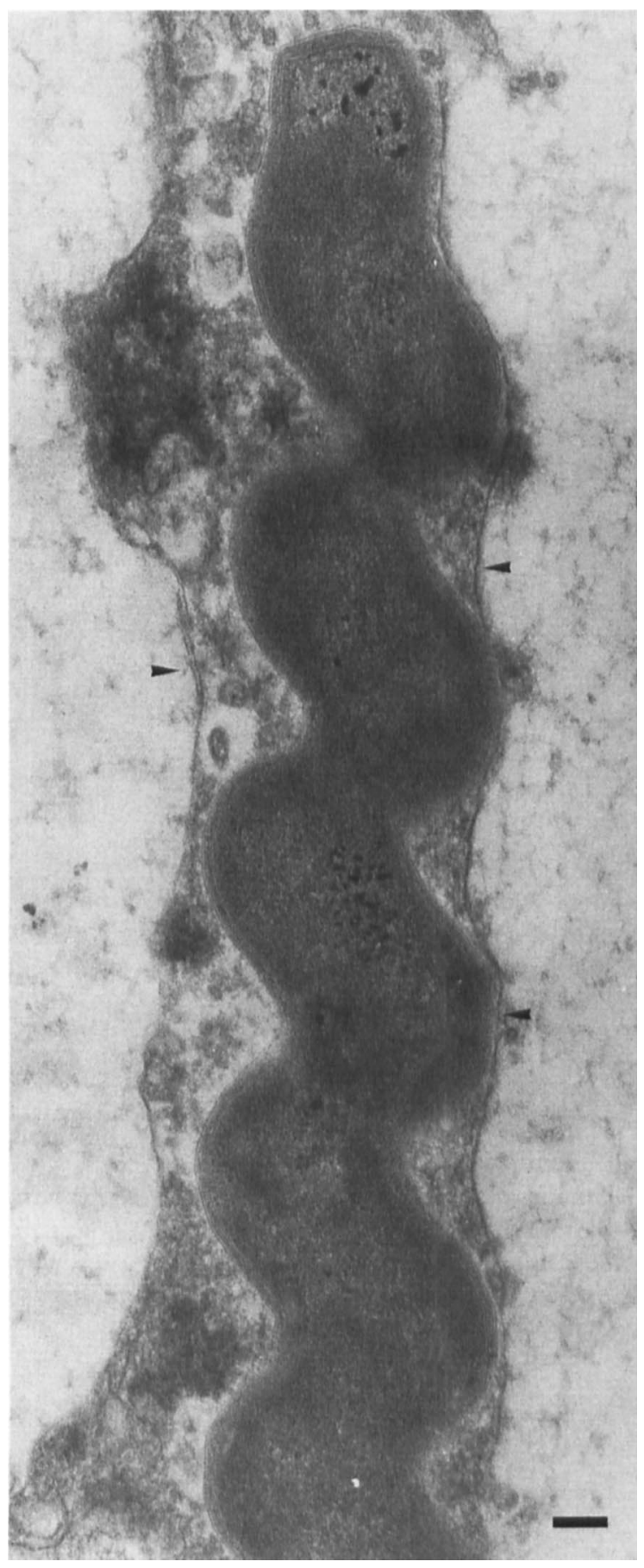

Fig. 2. Transmission electronmicrograph of a thin section of a pig spiral bacterium. The plasma membrane of an epithelial cell is shown by arrows $(-$ ). Bar, $0.1 \mu \mathrm{m}$. trilaminar unit membrane and an outer threelayered cell wall characteristic of gram-negative bacteria. The cell wall was smooth, approximately $9 \mathrm{~nm}$ thick and appeared as two electron-dense layers separated by a less dense zone (fig. 3). The cytoplasm contained sparse irregular non-membrane-bound granules, numerous ribosomes and large spherical or oval membrane-bound structures (fig. 4A and B). These structures appeared to be surrounded by a single-layered membrane and some of them had an extremely electron-dense core, frequently eccentric, and an electron-lucent halo.

Adjacent to the polar ends, at the region of insertion of the flagella, the cytoplasm had a less dense area, relatively free of ribosomes, that contained several irregular non-membrane-bound granules (figs. 1, 3 and 4A). On either side of this region, beneath the plasma membrane, there was a highly electron-dense "polar membrane" (figs. 3 and 4A). In some sections, this submembranous complex seemed to be continuous over the whole pole of the cell where it was closely adherent to the inner layer of plasma membrane (fig. 3).

Flagellar filaments of uniform width were seen arising from one polar end and consisted of a moderately dense homogeneous central core $(8 \mathrm{~nm})$ enveloped by an outer layer ( $7 \mathrm{~nm}$ ) (fig. $4 \mathrm{~A}$ and $\mathrm{C}$ ). In negatively stained preparations, the microorganisms were seen to have up to six flagella without terminal bulbs, arising from both poles.

Scanning electronmicroscopy showed that the micro-organism was helical shaped with tightly coiled spiral turns and with the extremities in opposite planes (fig. 5).

\section{Discussion}

Spiral micro-organisms have been observed in the gastric mucosa of several animal species but have received little further study. Interest in gastric spiral micro-organisms has gained impetus since the isolation of $H$. pylori from the stomachs of patients with gastritis and peptic ulcer. ${ }^{3}$ This bacterium is now accepted as being the main aetiological agent of human antral gastritis and probably is an essential factor in peptic ulcer disease. ${ }^{7}$ According to Lee and colleagues, ${ }^{5,14} \mathrm{H}$. pylori belongs to a special group of micro-organisms that colonise gut mucus. It is adapted to the human gastric mucosa and initially only primates ${ }^{15}$ and neonatal gnotobiotic pigs ${ }^{16,17}$ were colonised successfully by this bacterium. More recently, it was observed that $H$. pylori can also infect conventional pigs. ${ }^{18}$ Furthermore, Vaira et al. ${ }^{19}$ have demonstrated that abattoir workers have high titres of 


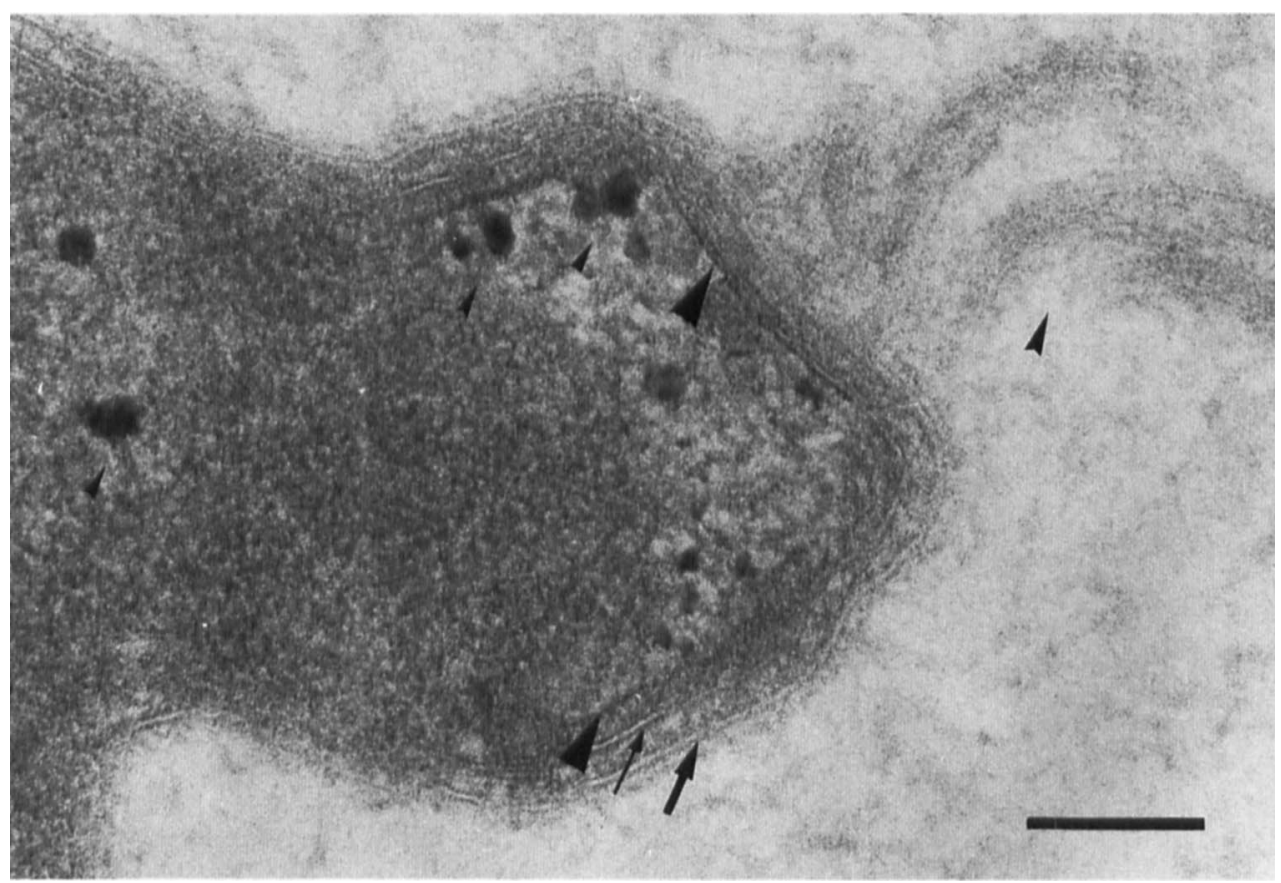

Fig. 3. Transmission electronmicrograph of an extremity of a spiral bacterium showing : non-membrane-bound granules $(>)$; polar membrane continuous over the whole pole of the cell $(-)$; flagella $(>)$; plasma membrane $(\rightarrow)$; and cell wall $(\Leftrightarrow)$. Bar, $0 \cdot 1 \mu \mathrm{m}$.

antibodies to $H$. pylori and they have suggested that this micro-organism may be transmitted to man from animals. For these reasons we searched for $H$. pylori in the stomachs of pigs which could be a natural reservoir of this micro-organism. We did not isolate $H$. pylori but we did observe a spiral organism, not previously described, morphologi-
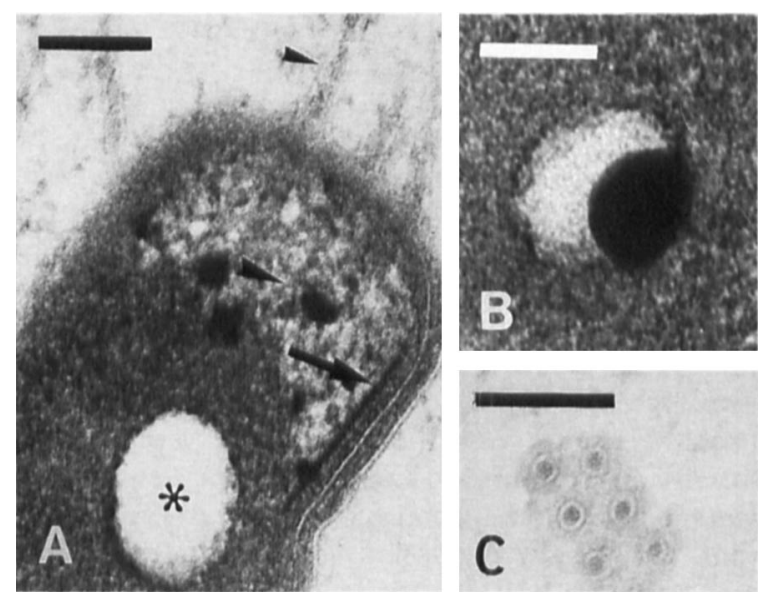

Fig. 4. Transmission electronmicrographs of spiral-shaped bacteria. (A) Extremity showing: membrane-bound granule without core $\left(^{*}\right)$; non-membrane-bound granule $(\boldsymbol{D})$; polar membrane $(\rightarrow)$; and longitudinal section of flagella $(\boldsymbol{D})$. Bar, $0.1 \mu \mathrm{m}$. (B) Membrane-bound granule with eccentric core. Bar, $50 \mu \mathrm{m}$. (C) Transverse sections of flagella. Bar, $0 \cdot 1 \mu \mathrm{m}$. cally similar to other gastric bacteria. Nevertheless, whereas the cat, monkey and dog gastric bacteria penetrate deep into the lumen of the gastric glands of the fundic mucosa and do not elicit structural changes in the host cells or any inflammatory response in the lamina propria, $2,5,6$ the pig microorganism, like $H$. pylori in man, colonised antral mucosa causing antral gastritis. ${ }^{8}$

The pattern of histological lesions caused by the pig bacterium resembled that observed in the stomachs of gnotobiotic pigs infected experimentally with $H$. pylori. ${ }^{16,20}$ Moreover, the pig gastric micro-organism shared other properties with $H$. pylori, including spiral morphology, high urease activity, and shallow penetration into the glands.

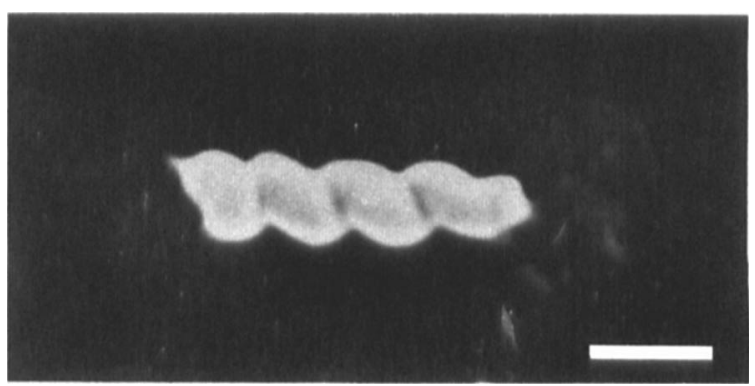

Fig. 5. Scanning electronmicrograph of a spiral-shaped bacterium. Bar, $0.5 \mu \mathrm{m}$. 
Studies that provide better comprehension of the relationship between pig spiral micro-organisms and gastric mucosa may add to our understanding of the interaction of $H$. pylori with the human gastric mucosa. Several aspects of gastric infection, such as the effects of chemotherapy, factors influencing gastric colonisation, and morphological and functional effects on gastric cells, could be elucidated by the use of this model.

Furthermore, a tightly spiral bacterium distinct from $H$. pylori has been observed on the gastric mucosa of patients with chronic active gastritis. $^{5,8,10,11}$ This bacterium was morphologically similar to the pig spiral organism and, like this, did not grow on laboratory media. It is possible that man could have acquired this tightly coiled spiral bacterium from animals, and pigs emerge as a probable source. ${ }^{10}$ Ultramicroscopic study of the pig gastric micro-organism would permit its comparison with that from man and could also provide information relevant to the taxonomy of these unclassified spiral organisms associated with gut mucus.

This group of bacteria presents several morphological properties in common and some dissimilarities. They also resemble Spirillum spp in some aspects such as size, rigid helical configuration and possession of bipolar tufts of flagella. ${ }^{21}$ However, the pig gastric spiral organism did not present the characteristic waviness observed in the outer portion of the cell wall of Spirillum spp. ${ }^{21,22}$ Furthermore, it did not have periplasmic fibrils, a striking feature reported in cat and dog gastric bacteria, 5,23 nor did it have the "cigar shaped" profile due to an outer-membrane-like wall component not closely adherent to the spiral body shown by the baboon gastric micro-organism. ${ }^{4}$

A polar membrane similar to that found in helical and flagellate micro-organisms such as Spirillum, ${ }^{20}$ Campylobacter, ${ }^{24,25}$ Ectothiorhodospira ${ }^{26}$ and Rhodospirillum spp. ${ }^{26}$ was also observed in the pig bacterium. The function of this submembranous complex associated with the cytoplasmic mem-

\section{REFERENCES}

1. Kasai, K, Kobayashi R. The stomach spirochaete occurring in mammals. $J$ Parasitol $1919 ; 6$; $1-11$.

2. Weber A F, Hasa $O$, Sauther J H. Some observations concerning the presence of spirilla in the fundic glands of dogs and cats. Am J Vet Res 1958; 19: 677-680.

3. Warren, J R, Marshall B J. Unidentified curved bacilli on gastric epithelium in active chronic gastritis ulceration. Lancet 1983; 1 : 1273-1274.

4. Curry A, Jones D M, Eldridge J. Spiral organisms in the baboon stomach. Lancet $1987 ; 2$ : 634-635. brane is not known but it might be involved in energy production for flagella motion. ${ }^{21}$ Although this structure has not been referred to by several authors in their reports of cat, ${ }^{2,5} \operatorname{dog}^{23}$ and monkey ${ }^{6}$ gastric bacteria, examination of their micrographs allowed us to observe its presence.

Some species of Spirillum have prominent granules of intracellular poly- $\beta$-hydroxybutyrate (PHB). ${ }^{26}$ These granules are unilaminar, membrane-enclosed and appear electron-transparent in thin section. ${ }^{27} \mathrm{PHB}$ is considered to be a cellular reserve of carbon or energy and the polymer accumulates when carbon and energy sources are in excess. ${ }^{27}$ Spiral bacteria from pigs showed unilaminar membrane-involved granules that sometimes had a central or eccentric electron-dense core. PHB granules with these characteristics have not been found in Spirillum, although they have been demonstrated in Bacillus cereus. ${ }^{27}$

Based on the ultrastructural features reported in this study, we suggest that the gastric microorganism from pigs should be included in the new genus "Gastrospirillum", proposed by McNulty et al. ${ }^{10}$ According to these authors, except for $H$. pylori, all spiral bacteria found in gastric mucosa of animals would be placed in this genus because they share several morphological characteristics with Spirillum. Moreover, a classification based on electronmicroscopy is permitted by rule 18 of the International Code of Nomenclature. ${ }^{28} \mathrm{We}$ also suggest that the bacterium from pigs should be named "Gastrospirillum suis".

It is expected that further study of " $G$. suis" will continue to expand our understanding of gastric disease and its relationship to spiral bacteria.

This work was supported by CNPq (Conselho Nacional de Desenvolvimento Cientifico e Tecnologico) and FINEP (Financiadora de Estudos e Projetos)-Brasil. We are grateful to $\mathrm{Mr}$ P. P. Silva for expert technical assistance, Mr I. D. Silva Neto for scanning electronmicroscopical advice and Dr W. de Souza who generously allowed us to use a Jeol-255-I-SEM of the Laboratorio de Microscopia Eletronica do Instituto de Biofisica Carlos Chagas Filho' UFRJ.

5. Lee A, Hazell S L, O'Rourke J, Kouprach S. Isolation of a spiral-shaped bacterium from the cat stomach. Infect Immun 1988; 56: 2843-2850.

6. Sato T, Takeuchi A. Infection by spirilla in the stomach of the rhesus monkey. Vet Pathol 1982; 19: Suppl: 17-25.

7. Graham D Y. Campylobacter pylori and peptic ulcer disease. Gastroenterol 1989; 96: 615-625.

8. Queiroz D M M, Rocha G A, Mendes E N, Lage A P, Carvalho A C T, Barbosa A J A. Spiral micro-organism in stomach of pigs. Vet Microbiol (in press).

9. Dent J C, McNulty C A M, Uff J C, Wilkinson S P, Gear 
M W T. Spiral organisms in the gastric antrum. Lancet 1987; 2: 96.

10. McNulty C A M, Dent J C, Curry A. New spiral bacterium in gastric mucosa. J Clin Pathol 1989; 42: 585-591.

11. Rocha, G A, Queiroz D M M, Mendes E N, Lage A P, Barbosa A J A. Simple carbol fuchsin staining for showing $C$. pylori and other spiral bacteria in gastric mucosa. J Clin Pathol 1989; 42: 1004-1005.

12. McNulty C A M, Wise R. Rapid diagnosis of Campylobacterassociated gastritis. Lancet $1985 ; 1$ : 1443-1444.

13. Coiro J R R, Weigl D R, Kiselins J, Menezes H, Billota J A T. A new embedding medium (Polylite 8001) for biological material. Cien Cult 1972; 24: 660-662.

14. Lee A, Hazell S L. Campylobacter pylori in health and disease: an ecological perspective. Microb Ecol Health Dis 1988; 1 : 1-16.

15. Newell D G, Hudson M J, Baskerville A. Naturally occurring gastritis associated with Campylobacter pylori infection in the rhesus monkey. Lancet 1987; 2: 1338.

16. Krakowka, S, Morgan D R, Kraft W G, Leunk R D. Establishment of gastric Campylobacter pylori infection in the neonatal gnotobiotic piglet. Infect Immun 1987; 55: 2789-2796.

17. Lambert J R, Borromeo $\mathbf{M}$, Pinkard $\mathrm{K}$ J, Turner $\mathrm{H}$, Chapman C B, Smith M L. Colonization of gnotobiotic piglets with Campylobacter pyloridis - an animal model? $J$ Infect Dis 1987; 155: 1344.

18. Jorgensen A, Egnstrand L, Soderlind O, Gustafsson S. Pigs as a model for Campylobacter pylori infection. Abstracts of the 10th International Congress of the Pig Veterinary Society $1988: 131$.
19. Vaira D, D'Anastasia C, Holton J. Campylobacter pylori in abattoir workers: is it a zoonosis? Lancet 1988; 2 : 725 726.

20. Murray R G E, Birch-Andersen A. Specialised structure in the region of the flagella tuft in Spirillum serpens. Can J Microbiol 1963; 9: 393-402.

21. Krieg N R. Biology of the chemoheterotrophic spirilla. Bacteriol Rev 1976; 40: 55-115.

22. Murray R G E. On the cell wall structure of Spirillum serpens. Can J Microbiol 1963; 9: 381-392.

23. Lockard V G, Boler R K. Ultrastructure of a spiraled microorganism in the gastric mucosa of dogs. Am J Vet Res $1970 ; 31$ : 1453-1462.

24. McCoy E C, Doyle D, Wiltberger H, Burda K, Winter A J. Flagellar ultrastructure and flagella-associated antigens of Campylobacter fetus. J Bacteriol 1975; 122: 307-315.

25. Goodwin C S, McCulloch R K, Armstrong J A, Wee S H. Unusual cellular fatty acids and distinctive ultrastructure in a new spiral bacterium (Campylobacter pylori) from the human gastric mucosa. J Med Microbiol 1985; 19: $257-267$.

26. Krieg N R. Aerobic/microaerophilic, motile, helical/vibrioid Gram-negative bacteria. In: Krieg N R, Holt J $\mathrm{G}$ (eds) Bergey's manual of systematic bacteriology, 1st edn. Baltimore, MD, Williams \& Wilkins Co. 1984: 71-124.

27. Shively $\mathbf{J}$ M. Inclusion bodies of prokaryotes. Annu Rev Microbiol 1974; 28: 167-187.

28. Lapage S P, Sneath P H A, Lessel E F, Skerman V B D, Seeliger H P R, Clark W A (eds). International code of nomenclature of bacteria. Washington DC, American Society for Microbiology. 1975 